\title{
IMPROVING SPEAKING ABILITY ON PUBLIC SPEAKING CLASS BY USING ROLE-PLAYING TECHNIQUE OF ENGLISH EDUCATION DEPARTMENT STUDENTS
}

\author{
Nafisah Endahati \\ Fakultas Keguruan dan Ilmu Pendidikan Universitas PGRI Yogyakarta \\ nafisah.indahatinya@gmail.com
}

\begin{abstract}
This research aims to improve speaking ability on speaking for specific purposes class of class A1 students of English Education Department students, Faculty of Teacher Training and Education, PGRI University of Yogyakarta in the academic year of 2012/2013. The effort which was done is using role-playing as a technique in teaching and learning activities.

This collaborative and participative action research consisted of three cycles, with plan, action, observation, and reflection in each cycle. The participants were the students of class A1 of English Education Department, Faculty of Teacher Training and Education, PGRI University of Yogyakarta. The data were collected by means of interviewing, recording technique, observing, and assessing. The qualitative data were analyzed through data reduction, data display and conclusion drawing, while the quantitative data was analyzed descriptively by counting the mean score and the score percentage of the result of the observation.

The results of research show that using role-playing technique can improve students' speaking ability on speaking for specific purposes class. It can be indicated by the improvement of the activity of speaking classroom English, the interaction between teacher and students, and the students and teacher's attention. The improvement of speaking ability on classroom English is also supported by the improvement of students' achievement in speaking performance to a mean score of 161,18 or $70,579 \%$ (cycle I), 176,31 or $76,956 \%$ (cycle II), and 198,16 or $85,797 \%$ (cycle III).
\end{abstract}

Key words: public speaking, collaborative, role playing technique

\section{Background to the Research}

English Education Department of Faculty of Teacher Training and Education of PGRI University of Yogyakarta has duty to prepare the students to become a professional teacher who has ability of conducting teaching students of junior and senior high. Besides having good ability in managing the English classroom, students have to acquire good written and oral English abilities. Linguistic competence is taught to complete students' performance.

Linguistics competence is taught to students in variety subjects. Those are phonology, pronunciation, morphology, semantics, and others. While improving students performance on English can be conducted by giving listening, speaking, 
writing, and reading subjects. Students are intended to master four language competencies as the preparation to deliver English in the classroom.

Students' ability in speaking is quite low. The low of speaking ability can be seen among students because of some factors, those are internal and external factors. The media, approach, and techniques of teaching language to students can be mentioned as the external factors of speaking ability inhibitors as well as environmental condition. The internal factors such as self-confident, motivation, attention, and curiosity may block students' comprehension through oral performance.

It can be concluded that the low of speaking ability are identified as follows. First, it is the low of students' self confidence, in producing the language. Second, it is the environmental condition which does not support oral ability. Third, it is the media of learning. Fourth, it is the implementation of uninteresting teaching technique in the classroom.

The focus of the research is on improving comprehension in speaking ability in Speaking for Specific Purposes class through the implementation of role-playing as teaching technique to students of English Education Department, Faculty of Teacher Training and Education, PGRI University of Yogyakarta. The students were class A1. They took Speaking for Specific Purposes subject. The implementation of role playing is intended to know how role playing technique will improve students' ability in speaking for specific purposes class. It also measures the result of the implementation of role playing technique in speaking for specific purposes class.

The research aims at improving process of teaching and learning in Speaking for Specific Purposes class. It also aims at improving the result of speaking ability in Speaking for Specific Purposes class, students of English Education Department, Faculty of Teacher Training and Education, PGRI University of Yogyakarta.

\section{Method}

The research is an action research. This is a qualitative in nature. The research consists of some steps. The steps are plan or draft, implementation the action, observation of the action, and reflection. Researcher makes syllabus, decides the goal of the learning process, designs the learning process, determines the method and technique of the research, prepares the learning materials and media, determines the group of performance, creates cozy and fun classroom, orders research instruments. 
The plan of the action then implemented to students of class A1, English Education Department, Faculty of Teacher Training and Education, PGRI University of Yogyakarta in the academic year of 2012/2013. The first implementation was the introduction and learning about English classroom expressions, consist of beginning of the lesson, during or whilst lesson, and end of the lesson.

Then, it is followed by preparing the groups of presentation or role playing. Along this preparation, each group determines the role of teacher and students. The group is given about 10 minutes of presentation. While a group is playing role, the others are the observers of the performance. While doing the presentation of role playing, the researcher and collaborator observe the presentation. Field notes are taken as needed. They tell about the real condition happen in the presentation. They are also useful to determine next action.

The material learning design which was planned by the researcher and collaborator were as follows. The role as a student, the student can:

a. Open the learning process and acquire: Expression of how to greet students, how to start the lesson, how to roll call, and how to introduce a topic.

b. Explain the lesson and acquire: Expressions of how to get started, how to give instructions, how to call on students, how to clarify student's answer, how to give verbal reward, and how to summarize and conclude the lesson.

c. Close the lesson and acquire: Expressions of how to signal time to stop, how to preview next class, how to leave the room, and how to close the lesson.

The role as student,

a. at the beginning of the lesson, the student acquire: Expression of how to respond to greeting, starting the lesson, rolling call, introducing a topic.

b. while teaching, the student acquire: Expressions of how to respond to getting started, giving instructions, calling on students, clarification, giving verbal reward, summarizing and concluding.

c. at the end of the lesson, the student acquire: Expressions of how to respond to signaling time to stop, previewing next class, leaving the room, and closing.

By using English in delivering the lesson, the ability in speaking English can be improved and hopefully can improve students' proficiency of teaching to learners. 
Because without giving experience in delivering lesson in front of the class, student will not be motivated to teach and they will lack of ability in speaking.

The research is an action research. This is a qualitative in nature. The purpose of the research is to improve the quality of the process and the result of learning. Madya (2007: 69) says that in classroom action research, the researcher involves in the research. Researcher plays important role in it. The researcher collaborates with the collaborator do the plans, observe, and finally make reflection.

Madya (2007: 69) mentions some steps in doing classroom action research. The steps are (1) identifying and finding the problem, (2) analyzing the problem, (3) formulating the hypothesis, (4) making the action plan and monitoring it, (6) processing and commenting on the data, and finally (7) reporting the result of the actions. In doing the steps, the researcher collaborates with the collaborator to do the whole steps.

The first step which was done by the researcher was identifying and stating the problem. Based on the interview done by the researcher to the students, it was concluded that the outstanding problem faced by the students were the low of students' speaking competence. The second step was analyzing the problem. Reality, the process of teaching-learning was still conventional. The use of media in speaking class did not improve students' competence in oral ability.

The third step done by the researcher was determining the action hypothesis. Based on the problem, it can be stated that by implementing role-playing the students' speaking competence will improve. The fourth step was making the action plan. In making the action plans, the researcher collaborated with the collaborator. They concluded that students conducted teaching process and played role as teacher and student.

The fifth step was doing the actions. The actions were conducted to students. The actions were directly observed and completed with field notes taken by the researcher and collaborator. The sixth step were processing and commenting on the data. The whole data taken from the field was observed accurately and the result of the observation became the source of reflection. The final step in the research was reporting the result of the actions research.

\section{Discussion}


Speaking is one of the subjects given to students as the way of improving student's competencies through language. Brown and Yule (Nunan, 1989: 56) mention that speaking is using verbal language which consists of short utterance, incomplete and separate in a range of pronunciation. Repetition may be done by one speaker and other, and they often use non-specific reference. Speaking competence covers monologue and dialogue skills (Brown, 2001). Monologue is one-way communication, while dialogue is two-ways communication. Monologue skill can be divided into planned and unplanned, while dialogue into personal and interpersonal skills. Interpersonal dialogue is intended to share information. This is divided into familiar and unfamiliar dialogue.

Balley (in Nunan, 2003: 54-56) mentions some principles of teaching speaking to students. The principles are as the following.

a. Be aware of the differences of the second language and foreign language learning context.

Language as a foreign language is in which the language is not used by the people in the country. It is as a foreign language. This situation, the students are challenged to use and study the target language.

b. Give students practice with both fluency and accuracy.

Accuracy is as much as the learner uses the target language when they use the language. While fluency is how far the speaker uses the language quickly and has self confidence to utter the language.

c. Provide opportunities for students to talk by using group work or pair work, and limiting teacher talk.

Experience is the best way to improve students' competence in speaking.

d. Plan speaking tasks that involve negotiation for meaning.

Speaking tasks that involve negotiation for meaning will help students to interact with others.

e. Design classroom activities that involve guidance and practice in both transactional and interactional speaking.

Transactional and interactional speaking can be reached through activities which is fun, enjoying, and motivating.

Brown (2004: 141-412) mentions taxonomy which describe as follows.

a. Imitative 
In this phase, student is expected to imitate a word, phrase, and sentence.

b. Intensive

It is the production of short structure which shows relation of grammar, phrase, lexical, and phonology.

c. Responsive

Responsive tasks includes interaction and comprehension test but in the limited level, such as short conversation, greetings, introduction, closing, simple asking questions and responding to questions in simple way.

d. Interactive

Speaking ability in interactive task deals with complex and long interaction between speaker and listener. It often mixes up with double participants. The purposes are exchanging information with others and keeping good relationships with others.

e. Extensive (monolog)

Tasks in extensive (monolog) deals with extensive performance such as speech, debate, presentation, and story-telling.

Nunan (1999: 226) states that the definition of speaking competence covers several points. The points are mentioned as follows;

a. Characteristics of communicative competence

Communicative competence includes knowing grammar and vocabulary, knowing the rules of speaking, knowing how to use and respond the variety of language, knowing how to use the language correctly.

b. Discourse versus dialogue

Conversation contains discourse. The speaker and listener negotiate meaning, regulate the conversation and maintain it. It is needed to give the students large time to practice speaking.

c. Transactional and interactional language

Transactional functions as getting and asking information from the process of speaking. Interactional language functions as maintaining social relationships. Speaking has to cover transactional and interactional functions.

d. Purposes of speaking

Conversation can be called as routines. Routines is the ways of how to convey meaning. It can be divided into information routines and interactional routines. 
e. Genre theory and speaking

Genre is communicative activities which are phases, purposeful, and socially structured.

Based on previous explanation, speaking skill is different with writing skill. Direct communication uses verbal language which spoken by the speaker using his organ of speech spontaneously according to the real situation. Littlewood $(1981,17)$ summarizes the functions of using language as verbal communication are as follows: serving a whole task practice, improving learning motivation, creating natural teaching-learning process, creating context which supports the teaching-learning process. To support the context of speaking, Harmer (2007, 348-352) advises some activities done in the classroom. Those are acting from a script, communication games, discussion, prepared talks, questionnaires, simulation and role play. Supporting Harmer's opinion, Balley (Nunan, 2003: 20) stakes some activities and techniques which can be applied in the classroom. Those are information gap, jigsaw activities, role play, simulations and contact assignment.

This research uses role play as its activity to improve students' comprehension through speaking for specific purposes class. Lee $(1986,147)$ describes role playing is an aspect of simulation. A whole situation is simulated in the classroom and the participants adopt roles which belong to it. Ladousse $(1987,6)$ describes functions of using role playing as a technique applied in the classroom. The functions are creating varieties of roles bringing students to the situation in which they speak the language pronounce in a specific situation, testing the target language, and motivating inferior student to show his performance. The important thing is that the activity conducting a fun situation.

While those considerations, the researcher applied role playing as technique to improve student's speaking ability. The students are asked to play role as student and teacher conducting the teaching-learning process in the classroom. There are three cycles promoting in the classroom. The indicators of the implementation of the role playing are the active speaking, the student-teacher interaction, the student-student interaction, and the improvement of score.

Role-playing technique considered as the best technique to improve the students' competency in speaking because of some considerations. Fist, role-playing is useful to help the language in the real situation of living and make natural 
experience to the learners in using target language in real situation. Second, roleplaying can improve students' competence in oral language and in understanding the target language. It can be said that role-playing can also help students to improve their social awareness to the others.

Before conducting the plans in cycle 1 , the researcher and the collaborator observed the problem faced by the students. The research which was done did to solve the problems faced by students in public speaking class by giving experience to students to use classroom English in the teaching-learning process. Meanwhile, the teaching process was divided into three phases, named pre-activity, whilst-activity, and post-activity.

Pre-activity was activity when the students responded greetings uttered by teacher. Responding the students' greetings was also emphasized in this phase. Whilst-activity was the content of teaching. In whilst-activity, students played role as teacher and students. It was the performance of role-playing. There were three steps in whilst-activity. The steps were opening, delivering, and closing the lessons. The last phase was post-activity. In post-activity, appreciation was given to the students for implementing role-playing to teach students. Students received advice and critics from the researcher and collaborator.

The action research had been done by the researcher. In cycle 1, the researcher gave material to students classroom English. Classroom English was introduced to students as the preparation of being teacher in role-playing. Cycle 1 indicated that the result of the implementation of role playing technique was still unsuccessful. It can be seen by students' low score. The indicator of active speaking could not reach successful. The students were active when they played as teacher role. The students tried to perform well in handling as teachers although they did not use media as teaching facilitator. They mostly used only discussion and question-answer to deliver the lesson to students.

As a student role, they seemed passive. The student never interacted with others although they were in one group of role-playing. The indicator of studentteacher interaction was good, but there was not good result on student-student interaction. By reading field notes, it can be concluded that students uttered some mistakes on English classroom instruction grammatically and orally. The students uttered the English language classroom unnatural and unsystematically. 
Students were assessed their performance by the researcher and collaborator. After implementing cycle 1, the researcher and the collaborator decided to implement activity to help students' comprehension through English vocabulary, grammar, and pronunciation. The activity was conducted in the first meeting of cycle 2 . The researcher taught the students basic learning on English pronunciation and gave students task about other utterances can be delivered in classroom English. The researcher also asked the students as teacher role to use media as teaching facilitator. The media would make the teacher role easier to deliver the material.

The implementation of cycle 2 was conducted at three meetings. First meeting was learning about the English sounds, explaining about the use of media as teaching facilitator, making correction on students' grammatical error. Second and third meetings were the implementation of role playing in the classroom. After the implementation of role playing, researcher and collaborator reflected the result of students' performance. Generally, the improvement of active speaking still seemed unsuccessful. The use of translation in teaching learning process made the process of teaching learning process not meaningful. In delivering the material, the student who played as teacher role used translation from English to Indonesia language. The use of media helped the teacher role conduct the material interestingly.

Besides the improvement of the active speaking, the use of media could stimulate the interaction between teacher and students. The communication between teacher and students were contextual. The student-student interaction could not be said successful because the teaching learning process was dominated by teacher role. The use of media was centered to teacher role. The expression of English classroom could be uttered well although mostly conducting by teacher role.

The students' performance was assessed by researcher and collaborator. Generally, the score of the speaking performance was unsuccessful. Most of students got better score in opening and closing classroom English, but in whilst teaching score, they were low. In reflecting the result of the implementation of role playing, researcher discussed with the collaborator. Collaborative discussion between researcher and collaborator was done to reach better improvement on students' speaking performance.

Based on the discussion, it was concluded that there were needed to implement some considerations. Those were asking the students who played role as 
teacher not to use translation in delivering materials, asking students who played role as teacher to do activities which stimulate student-student interaction, and drilled students to pronounce correct English sounds.

The implementation of cycle 3 was done well. As previous cycle, there were three meetings. Based on the observation of the implementation of role playing technique, the researcher and collaborator discussed and evaluated together. It can be concluded that all indicators of improving students' speaking ability were successful except the interaction of student-student. In this action research, the use of role playing technique could not improve student-student interaction. There were no contextual interaction between student and student. There were only non-verbal communications between student-student. Because students had to prepare and do final semester test, the researcher and collaborator concluded to end the action research.

\section{Conclusion}

The process of classroom speaking for specific purposes has ended. The results of the action implemented to improve students' speaking ability can be drawn as follows. First, the process of teaching learning English using role playing as teaching technique has improved class A1 students' speaking ability. It can be seen by the active speaking using English language, verbal interaction between student who plays role as teacher and the student who plays role as student. The verbal interaction happens in the process of teaching learning situation.

The ability of speaking English for specific purposes that is the English classroom of the students of class A1 English Education Department of Faculty of Teacher Training and Education also raises. The result is supports by the improvement of the mean score assessed by the researcher and collaborator to the process of role playing technique from 161.18 (cycle 1), 176.31 (cycle 2), and 198.16 (cycle 3). Generally, the improvement of the result can be drawn as from cycle 1 to cycle 2 is 15.13 or $6.377 \%$ and from cycle 2 to cycle 3 is 21.85 or $8.841 \%$.

\section{References}

Brown, H. Douglas. (2001). Teaching by principles: an interactive approach to language pedagogy $\left(2^{\text {nd }}\right.$ ed $)$. New York: Pearson Education Company.

Harmer, Jeremy.(2007). The practice of english language teaching $\left(4^{\text {th }} \mathrm{ed}\right)$. New York: Pearson Longman. 
Ladousse, Gillian P. (1987). Role play. Oxford: Oxford University Press.

Lee, W.R. (1986). Language teaching games and contests $\left(2^{\text {nd }} e d\right)$. New York: Oxford University Press.

Littlewood, William. (1981) Communicative language teaching; an introduction. Cambridge: Cambridge University Press.

Nunan, David. (1989). Designing task for the communicative classroom. Cambridge: Cambridge University Press.

Nunan, David. (2003). Practical english language teaching. New York: Mc.GrawHill Companies.

Suwarsih Madya. (2007). Teori dan praktik penelitian tindakan. Bandung: Alfabeta. 